\title{
Lewis Acid Promoted Trapping of Chiral Aza-enolates
}

\author{
Francesco Lanza \\ Juana M. Pérez \\ Ravindra P. Jumde \\ Syuzanna R. Harutyunyan* (i) \\ Stratingh Institute for Chemistry, Rijksuniversiteit Groningen, \\ Nijenborgh 4, 9747 AG, Groningen, The Netherlands \\ s.harutyunyan@rug.nl \\ Published as part of the 50 Years SYNTHESIS - Golden Anniversary Issue
}

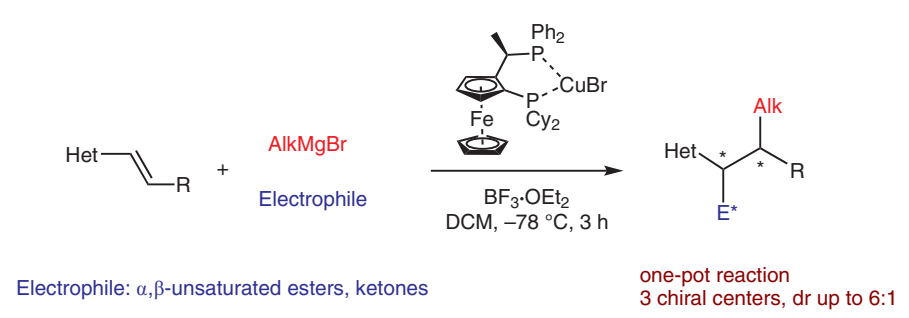

3 chiral centers, dr up to $6: 1$

\author{
Received: 07.12.2018 \\ Accepted after revision: 17.12 .2018 \\ Published online: 29.01 .2019 \\ DOI: 10.1055/s-0037-1611657; Art ID: ss-2018-z0823-op \\ License terms: $(9)(-)(-)$
}

Abstract We present a study on sequential conjugate addition of Grignard reagents to alkenyl-heteroarenes followed by trapping of the resulting enolates, yielding moderate to good diastereoselectivities. Contrary to conventional wisdom, one-pot conjugate addition/trapping using two reactive Michael acceptors in combination with Grignard reagents can proceed via conjugate addition to the least reactive Michael acceptor. This unusual chemoselectivity is triggered by the presence of a Lewis acid, reverting the usual reactivity order of Michael acceptors.

Key words aza-enolate trapping, copper catalyst, Lewis acid, conjugate addition, one-pot reaction

The construction of molecular scaffolds with multiple stereocenters has always been a major challenge in organic chemistry. One of the possible approaches to address this challenge is through conjugate additions of organometallics to afford metal enolates that can be trapped with electrophiles, thus generating two or more stereocenters. The presence of multiple stereocenters makes controlling their absolute and relative configurations a difficult task. Methods employing compounds that can undergo intramolecular trapping ${ }^{1}$ or cyclic substrates ${ }^{2-4}$ have emerged as principal strategies to harness the diastereoselectivity of the process. Moreover, regardless of the cyclic or acyclic substrate employed, addition of co-solvents and/or additives is often required to increase the reactivity of the corresponding enolates and to further improve the outcomes of the processes. ${ }^{5}$ We recently reported the highly enantioselective catalytic transformation of a wide range of $\beta$-substituted conjugated alkenyl- $N$-heteroaromatics into their corresponding chiral alkylated products via Lewis acid activation in combination with highly reactive Grignard reagents and a chiral copper catalyst. ${ }^{6}$ Aza-enolates are the products of this transforma- tion before the reaction is quenched. During this investigation we encountered the formation of an unknown side product in some specific reactions. Isolation and full characterization of the latter led us to identify it as compound $\mathbf{2 a}$, resulting from the trapping of aza-enolate 1a' by another molecule of substrate 1a (Scheme 1). Hereafter, the process leading to the formation of compound $\mathbf{2 a}$ will be referred to as 'auto-trapping'. Remarkably, compound 2a was formed as a single diastereoisomer with high enantioselectivity ( $97 \%$ ee), despite the presence of three stereocenters. This unexpected reactivity and diastereoselectivity prompted us to investigate alkenyl-heteroarenes in a tandem conjugate addition/enolate trapping reaction sequence, aiming to access chiral heteroarenes with both $\alpha$ and $\beta$-stereocenters, as is commonly encountered in bioactive compounds.

To study the reactivity of the resulting aza-enolate towards trapping with electrophiles, the conjugate addition of EtMgBr to (E)-2-styrylbenzo[d]oxazole (1) $\mathbf{b})$ in DCM at $-78^{\circ} \mathrm{C}$ in the presence of $\mathrm{BF}_{3} \cdot \mathrm{Et}_{2} \mathrm{O}$ as a Lewis acid was selected as model reaction (Scheme 2). In the presence of chiral catalyst $\mathbf{C u}-\mathbf{L 1}$, the conjugate addition step typically proceeded with $97 \%$ enantioselectivity and full conversion into the addition product. To ensure the completion of the addition reaction, the electrophile was added 3 hours after the start of the reaction at the same temperature, followed by warming to room temperature (R.T.) and further stirring for several hours.

Initial attempts to trap the aza-enolate formed upon conjugate addition using $\mathrm{MeI}(\mathbf{3 a})$ and $\mathrm{BnBr}(\mathbf{3 b})$ as electrophiles resulted in recovery of only conjugate addition product 5. Significant conversion towards trapping product 4 was observed when more reactive benzaldehyde (3c) (30\%) and ethyl crotonate (2d) (54\%) were used as electrophiles. Remarkably, in both cases, only two diastereoisomers were detected in the crude NMR spectra, in 2:1 and 1:1 ratios, respectively (Scheme 2). 


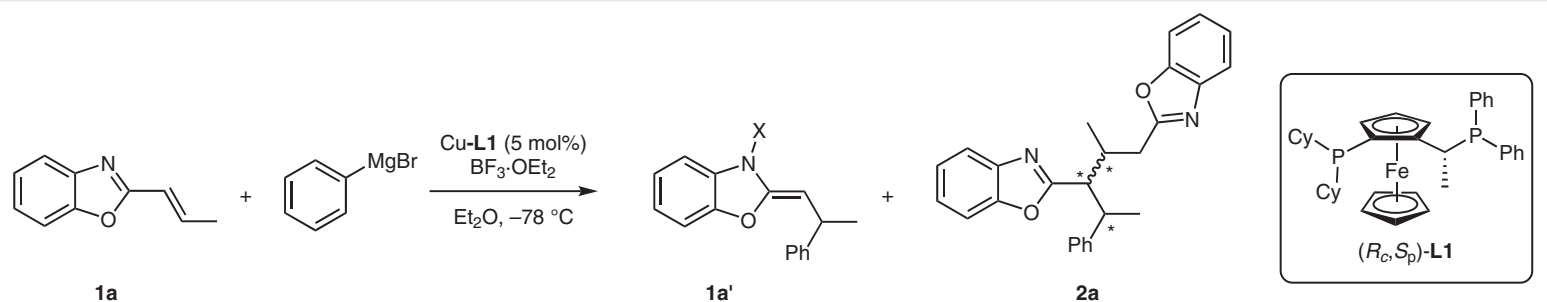

1a

$$
\mathrm{X}=\mathrm{BF}_{3} \text { or } \mathrm{MgBr}
$$

Scheme 1 Auto-trapping of 1 a upon conjugate addition of $\mathrm{PhMgBr}$

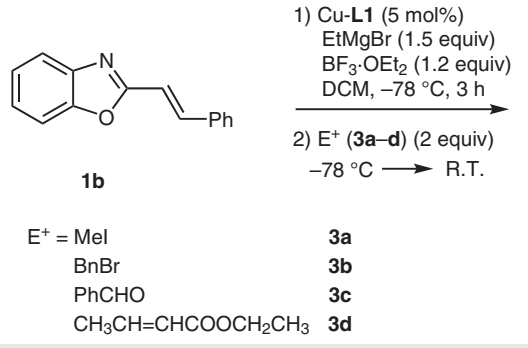

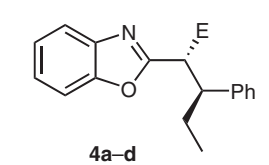

$4 a-d$

Conversion $\quad 4 a=0 \%$

Conversion $\mathbf{4 b}=0 \%$

Conversion $\mathbf{4 c}=30 \%, \mathrm{dr}=2: 1$

Conversion $\mathbf{4 d}=54 \%, d r=1: 1$

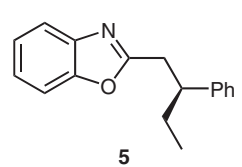

$\mathbf{5}=99 \%$

$\mathbf{5}=99 \%$

$\mathbf{5}=70 \%$

$5=46 \%$

Scheme 2 Sequential Asymmetric Conjugate Addition (ACA)/enolate trapping of $\mathbf{1} \mathbf{b}$ with alkylating agents

In an attempt to improve the stereoselectivity, the reaction using ethyl crotonate (3d) as the electrophile was performed while keeping the temperature constant at $-78^{\circ} \mathrm{C}$, also after the addition of the electrophile. This was indeed beneficial, with the diastereoisomeric ratio (dr) increasing from 1:1 to 6:1 without any significant loss in terms of conversion. With these reaction conditions in hand, we decided to study the influence of the addition of compound $\mathbf{3 d}$ at different reaction times (Table 1 ).

We found that the timing for the addition of the electrophile was important for the trapping efficiency. Increasing the time gap between conjugate addition and addition of the electrophile from 3 to 16 hours led to a significant decrease in the amount of enolate-trapped product (Table 1 , entries 1 and 2). In trapping reactions of reactive enolates with reactive electrophiles it is common to add the electrophile in excess and only when the corresponding enolate has been formed. It is never added to the reaction mixture before the actual conjugate addition is complete, in order to avoid an obvious side reaction derived from the addition of the organometallic to an electrophile instead of the substrate. In our particular case, crotonate $\mathbf{3 d}$ is expected to be more reactive towards Grignard addition than the alkenylheteroarene substrate $\mathbf{1 b}$. Furthermore, it is known that the same catalytic system (Cu-L1) in combination with Grignard reagents is the system of choice for catalytic asymmetric additions to crotonates. ${ }^{7}$ Therefore, addition of crotonate $\mathbf{3 d}$ to the reaction mixture from the start (or in other

Table 1 Addition of the Electrophile at Different Reaction Times ${ }^{\mathrm{a}}$

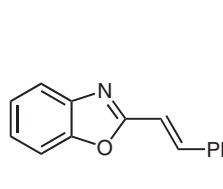

$1 b$

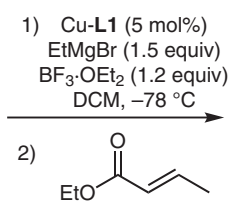

$3 d$

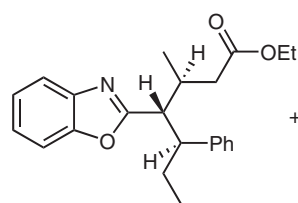

4d

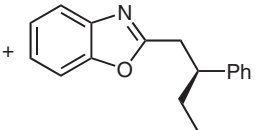

5

\begin{tabular}{lccc}
\hline Entry & Time gap & 3d:4 & dr \\
\hline 1 & $16 \mathrm{~h}$ & $40: 60$ & $2: 1$ \\
2 & $3 \mathrm{~h}$ & $50: 50$ & $6: 1$ \\
\hline
\end{tabular}

${ }^{a}$ Reaction performed using compound $\mathbf{1 b}$ (1 equiv), CuBr$\cdot \mathrm{SMe}_{2}$ (5 mol\%), L1 (6 mol\%), EtMgBr (1.5 equiv), BF $\mathrm{BEt}_{2}$ (1.2 equiv), and $\mathbf{3 d}$ (4 equiv) in DCM

$(1 \mathrm{~mL} / \mathrm{mmol})$ at $-78^{\circ} \mathrm{C}, 3 \mathrm{~h}$ after addition of the electrophile.

b Determined via NMR spectroscopy. 

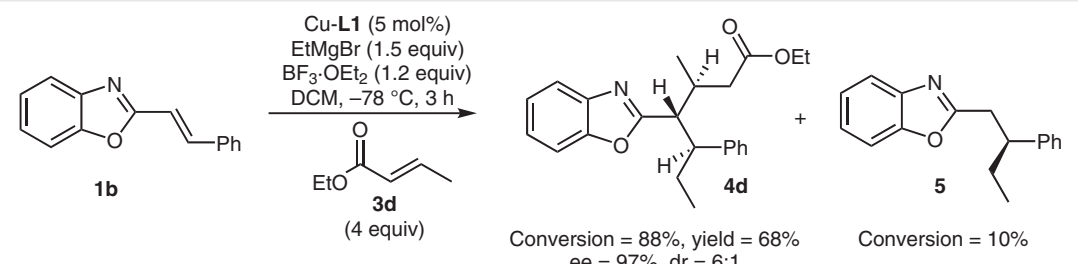

Scheme 3 One pot ACA/enolate trapping of $\mathbf{1 b}$ with ethyl crotonate (3d)

words, a one-pot reaction) prior to addition of the Grignard reagent is rather counterintuitive and would be expected to fail. However, based on our previous observations of 'autotrapped' products, we decided to perform the reaction in this way. Remarkably, introducing the electrophile $\mathbf{3 d}$ at the beginning of the reaction prior to addition of the Grignard reagent provided the aza-enolate trapping product $\mathbf{4 d}$ as the main product, with only small amounts of conjugate addition product $\mathbf{4}$ and no traces of conjugate addition of the Grignard reagent to crotonate $\mathbf{3 d}$, despite it being present in excess ( 4 equiv) at the beginning of the reaction (Scheme 3).

In order to explain these results, we hypothesize that the presence of the Lewis acid is essential for this observed chemoselectivity. We believe that $\mathrm{BF}_{3} \cdot \mathrm{OEt}_{2}$ binds selectively to the more basic substrate, namely alkenyl-heteroarene $\mathbf{1 b}$, thus transforming it into a more reactive Michael acceptor than crotonate 3d. This hypothesis is supported by NMR experiments which indeed show full binding of $\mathrm{BF}_{3} \cdot \mathrm{OEt}_{2}$ to $\mathbf{1 b}$, whilst in the case of $\mathbf{3 d}$ the equilibrium was shifted towards the non-bound state (see the Supporting Information, Figure S1). Upon addition of EtMgBr to the alkenylheteroarene two possible enolate species can be formed, namely a boron-aza-enolate ${ }^{8}$ and a magnesium-aza-enolate. $^{9}$

In our hypothesis, one of the two possible enolate species is the kinetic, highly reactive enolate, that is replaced over time by the less reactive thermodynamic enolate. Unfortunately, we were not able to confirm this by NMR. In this scenario, the immediate availability of $\mathbf{3 d}$ would favor the trapping of the most reactive enolate, while delayed addition of $\mathbf{3 d}$ to the reaction mixture should result in a lower conversion, as shown in Table 1.

Next, we studied the effect of the concentration of $\mathbf{3 d}$ (Table 2). From the data obtained, it is clear that a large excess of ester 3d is required in order to achieve higher conversion toward the trapping product. Interestingly, the auto-trapping product $\mathbf{2 b}$ becomes more prominent when the amount of 3d drops below 4 equivalents.

We have also looked into the effect of various Lewis acids on the course of the reaction. Trimethylsilyl triflate (TMSOTf) failed in promoting not only the enolate trapping but also the conjugate addition to $\mathbf{1 b}$, with the conjugate addition to ethyl crotonate (3d) being the only pathway ob-
Table 2 Optimization of the Concentration of Electrophile $\mathbf{3} \mathbf{d}^{\mathrm{a}}$

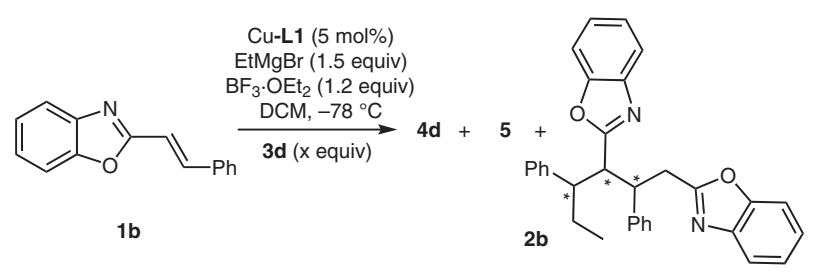

\begin{tabular}{lccc}
\hline Equiv of 3d & $\mathbf{4 d}(\%)^{\mathrm{b}}$ & $\mathbf{5}(\%)^{\mathrm{b}}$ & $\mathbf{2 b}(\%)^{\mathrm{b}}$ \\
\hline 1.2 & 10 & 54 & 36 \\
2.0 & 18 & 60 & 22 \\
2.5 & 73 & 15 & 12 \\
4.0 & 88 & 10 & traces \\
\hline
\end{tabular}

${ }^{a}$ Reaction carried out using compound $\mathbf{1 b}$ ( 1 equiv), $\mathrm{CuBr} \cdot \mathrm{SMe}_{2}$ ( 5 mol\%), L1 (6 mol\%), EtMgBr (1.5 equiv), and $\mathrm{BF}_{3} \cdot \mathrm{OEt}_{2}$ (1.2 equiv) in DCM (1 $\mathrm{mL} / \mathrm{mmol})$ at $-78^{\circ} \mathrm{C}, 3 \mathrm{~h}$.

${ }^{\mathrm{b}}$ Determined via NMR spectroscopic analysis.

served. When $\mathrm{BCl}_{3}$ and $\mathrm{BBr}_{3}$ were used as Lewis acids, compounds 6 and 7, derived from $N$-acylation of the conjugate addition product $\mathbf{5}$, were formed predominantly (Figure $\mathbf{1}$ ).

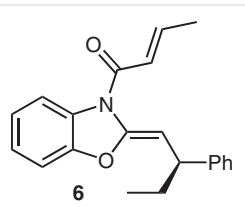

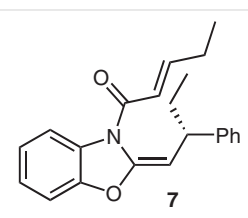

Figure 1 N-Acylation products 6 and 7

Looking more carefully at the reaction promoted by $\mathrm{BF}_{3} \cdot \mathrm{OEt}_{2}$, we noticed that compounds $\mathbf{6}$ and $\mathbf{7}$ were also formed under these reaction conditions, but in lower amounts (ca. 5\%). From this short screening of Lewis acids, $\mathrm{BF}_{3} \cdot \mathrm{OEt}_{2}$ emerged as the optimum choice for this transformation.

With optimized conditions in hand, the reaction was tested using different carbonyl electrophiles (Table 3 ). Among all the Michael acceptors tested, only ester $\mathbf{3 d}$ and ethyl cinnamate (3e) furnished the desired enolate-trapping products in moderate yields and high enantioselectivities. $\beta, \beta$-Substituted Michael acceptor 3f was not suitable 
Table 3 Scope of the Reaction Using Different Electrophiles ${ }^{\mathrm{a}}$
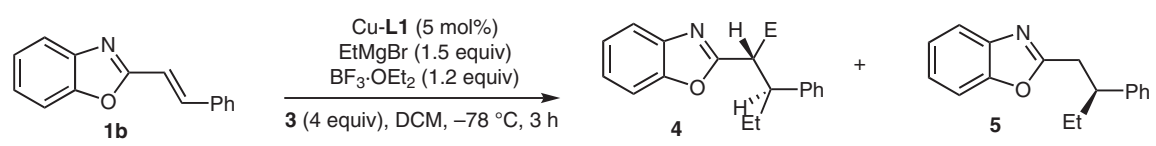

\begin{tabular}{|c|c|c|c|c|c|c|c|c|c|c|c|c|c|}
\hline Entry & Electrophile & 3 & $4: 5^{b}$ & Yield (\%) & $\mathrm{dr} r^{\mathrm{b}}$ & ee $(\%)^{d}$ & Entry & Electrophile & 3 & $4: 5^{b}$ & Yield (\%) & $\mathrm{dr} r^{\mathrm{b}}$ & ee $(\%)^{d}$ \\
\hline 1 & & $3 d$ & $88: 10$ & 68 & $6: 1$ & 97 & $6^{e}$ & & $3 \mathbf{i}$ & - & - & - & - \\
\hline 2 & & $3 e$ & $76: 24$ & 49 & $2.5: 1: 1$ & 91 & $7^{e}$ & & $3 \mathbf{j}$ & - & - & - & - \\
\hline 3 & & $3 f$ & $0: 100$ & - & - & - & $8^{e}$ & & $3 k$ & - & - & - & - \\
\hline 4 & & $3 g$ & $27: 30$ & n.d. & $2.8: 1$ & n.d. & 9 & & 31 & $100: 0$ & 40 & $3: 1: 1^{f}$ & 97 \\
\hline $5^{e}$ & & $3 \mathrm{~h}$ & - & - & - & - & 10 & & $3 m$ & 100:0 & 52 & $1.7: 1^{f}$ & 97 \\
\hline $\begin{array}{l}\text { a Rea } \\
\text { DCM } \\
\text { b Det } \\
\text { ' } \text { ' Yiel } \\
\text { d Det } \\
\text { e Unr } \\
\text { }{ }^{\circ} \text { All f }\end{array}$ & $\begin{array}{l}\text { carried out u } \\
\text { L/mmol) at } \\
\text { hed via NMR } \\
\text { isolated dias } \\
\text { hed via HPLC } \\
\text { d benzoxazo } \\
\text { ossible diast }\end{array}$ & $\begin{array}{l}\text { ompol } \\
3 \mathrm{~h} \text {. } \\
\text { oscop } \\
\text { omer } \\
\text { is. } \\
\text { ecove }\end{array}$ & $\begin{array}{l}\text { d } \mathbf{1 b} \text { (1 e } \\
\text { mixtures }\end{array}$ & $\begin{array}{l}\text { iv), CuBr.SN } \\
\text { d. = not de } \\
\text { products o }\end{array}$ & $\begin{array}{l}\mathrm{Me}_{2}(5 \mathrm{~mol} \\
\text { termined. } \\
\text { f conjugat }\end{array}$ & ddition & l\%), EtM & & & equiv), a & Michael acc & ceptor (4 & equiv) in \\
\hline
\end{tabular}

for this transformation (entry 3), while $N, N$-dimethyl crotonamide $(\mathbf{3 g}$ ) showed some reactivity but with a lower conversion than its ester analogue 3d (compare entries 1 and 4 ). In the presence of more reactive Michael acceptors such as methyl acrylate ( $\mathbf{3 h}$ ), lactone $\mathbf{3 i}$, and enones $\mathbf{3} \mathbf{j}$ and 3k, conjugate addition to the latters became the predominant process (entries 5-8), with $\mathbf{1 b}$ recovered at the end of the reaction. To our delight, two very reactive aromatic (31) and aliphatic (3m) ketones (entries 9 and 10), that are common substrates for alkylations with Grignard reagents and that can also be catalyzed by the same $\mathrm{Cu}$-based catalytic system, ${ }^{10}$ also proved to be suitable electrophiles for our trapping protocol, providing the corresponding $\alpha$-tertiary alcohols in moderate yields, albeit with a drop in the diastereoselectivities.
These results provide us with a rough idea on the reactivity of the Lewis activated compound $\mathbf{1 b}$, placing it between a ketone and an ester in a hypothetical reactivity scale (Figure 2).

To conclude our investigation, we studied the influence of the nature of the alkenyl-heteroarenes on the efficiency of the trapping process (Table 4). The results shown in Table 4 indicate that the process is strongly substrate dependent, with only benzoxazoles and analogous compounds undergoing the enolate trapping (entries 1-3 and 5). Pyridine 1f displayed a lower reactivity with only $36 \%$ conversion toward $\mathbf{4 r}$ (entry 6), while substrate $\mathbf{1 g}$ yielded a complex reaction mixture (entry 7 ). Other substrates containing quinoline, pyrimidine or triazine moieties, unfortunately did not afford any trapping product (entries 8-12). However, it is worth noting that in all these cases the addition of EtMgBr proceeded towards the heteroarene substrate in the presence of the more reactive crotonate $\mathbf{3 d}$.
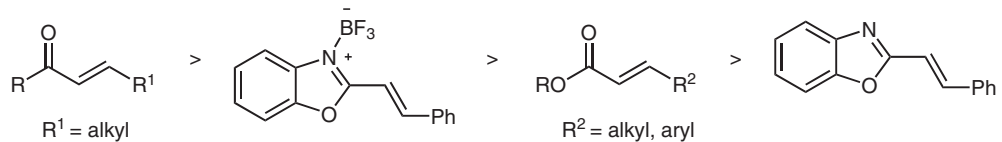

Figure 2 Hypothetical reactivity scale of Michael acceptors 
Table 4 Scope of the Reaction Using Different Heterocycles ${ }^{\mathrm{a}}$

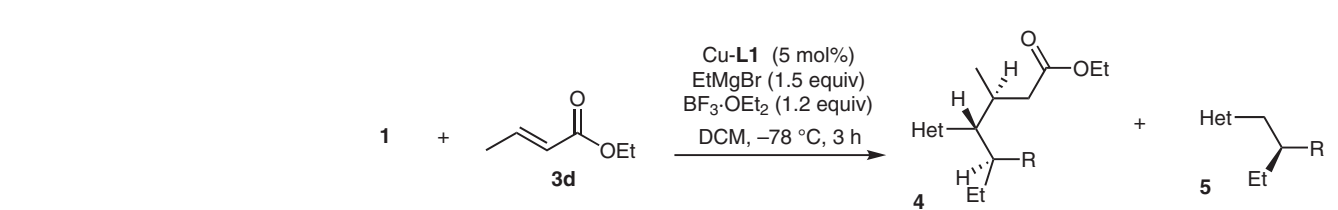

Entry Substrate

${ }^{a}$ Reaction carried out using substrate $\mathbf{1}$ (1 equiv), CuBr.SMe 2 (5 mol\%), $\mathbf{L} \mathbf{1}$ (6 mol\%), EtMgBr (1.5 equiv), $\mathrm{BF}_{3} \cdot \mathrm{OEt}_{2}(1.2$ equiv), and ethyl crotonate (3d) (4 equiv) in $\mathrm{DCM}(1 \mathrm{~mL} / \mathrm{mmol})$ at $-78^{\circ} \mathrm{C}, 3 \mathrm{~h}$; the absolute configuration is established based on the X-ray crystal structure of product $\mathbf{4 o}$.

${ }^{b}$ Determined via NMR spectroscopy.

' Yields of isolated products; n.d. = not determined.

d Determined via HPLC analysis.

e 3.0 equivalents of TMSOTf and 10\% of Cu-L1 were used.

${ }^{f}$ Determined via GC-MS.

In conclusion, a one-pot procedure for the conjugate addition of alkenyl-heteroarenes with subsequent trapping of the resulting aza-enolate with Michael acceptors has been explored. The process shows high stereoselectivity, but the high specificity for oxazole and benzoxazole derivatives, as well as for $\alpha, \beta$-unsaturated esters, limits the scope of its application. Interestingly, the superior affinity of $\mathrm{BF}_{3} \cdot \mathrm{OEt}_{2}$ towards the more Lewis basic benzoxazole resulted in a drastic change in reactivity order, allowing the conjugate addition to the latter to occur in the presence of commonly more electrophilic esters, thus facilitating one-pot conjugate addition/trapping reactions with alkenyl-heteroarenes.

Unless otherwise indicated, reagents and substrates were purchased from commercial sources and used as received. Solvents not required to be dry were purchased as technical grade and used as received. Dry solvents were freshly collected from a solvent purification system prior to use. All reactions using oxygen- and/or moisture-sensitive materials were carried out with anhydrous solvents (vide infra) under a nitrogen (dried over $\mathrm{P}_{2} \mathrm{O}_{5}$ ) atmosphere using oven-dried glassware and standard Schlenk techniques. Grignard reagents were purchased from Sigma-Aldrich and used as received (EtMgBr, $3 \mathrm{M}$ in $\mathrm{Et}_{2} \mathrm{O}$; $\mathrm{PhMgBr}, 3 \mathrm{M}$ in $\mathrm{Et}_{2} \mathrm{O}$ ). Unless otherwise noted substrates were prepared by literature methods (vide infra). Chiral ligands (RevJosiphos) were purchased from Solvias. All reported compounds were characterized by ${ }^{1} \mathrm{H}$ and ${ }^{13} \mathrm{C}$ NMR spectrometry and compared with literature data. All new compounds were fully characterized by ${ }^{1} \mathrm{H}$ and ${ }^{13} \mathrm{C}$ NMR spectrometry and HRMS techniques.

Reactions were monitored by ${ }^{1} \mathrm{H}$ NMR. Purification of the products, when necessary, was performed by flash column chromatography using Merck 60 A 230-400 mesh silica gel. NMR data was collected on Bruker Avance NEO $600\left({ }^{1} \mathrm{H}\right.$ at $600.0 \mathrm{MHz} ;{ }^{13} \mathrm{C}$ at $\left.150.87 \mathrm{MHz}\right)$, equipped with a Prodigy Cryo-probe, Varian Inova $500\left({ }^{1} \mathrm{H}\right.$ at 500.0 $\mathrm{MHz} ;{ }^{13} \mathrm{C}$ at $125.72 \mathrm{MHz},{ }^{19} \mathrm{~F}$ at $470.37 \mathrm{MHz}$ ), equipped with an indirect detection probe, and Varian VXR400 $\left({ }^{1} \mathrm{H}\right.$ at $400.0 \mathrm{MHz} ;{ }^{13} \mathrm{C}$ at 
100.58 MHz, ${ }^{19} \mathrm{~F}$ at $376.29,{ }^{31} \mathrm{P}$ at $161.94 \mathrm{MHz}$ ), equipped with a $5 \mathrm{~mm}$ $z$-gradient broadband probe, spectrometers. Chemical shifts are reported in parts per million (ppm) relative to the residual solvent signal ( $\left.\mathrm{CDCl}_{3},{ }^{1} \mathrm{H}: 7.26 \mathrm{ppm} ;{ }^{13} \mathrm{C}: 77.16 \mathrm{ppm}\right)$. Coupling constants are reported in hertz. Multiplicities are reported with standard abbreviations ( $\mathrm{s}$ : singlet, br s: broad singlet, d: doublet, dd: doublet of doublets, ddd: doublet of doublet of doublets, t: triplet, td: triplet of doublets, q: quartet, dq: doublet of quartets, quin: quintet, sext: sextet, sept: septet, m: multiplet). High-resolution mass spectrometry was performed using an LTQ Orbitrap XL apparatus with ESI ionization. Enantiomeric excesses (ee) were determined by chiral HPLC analysis using a Shimadzu LC-10ADVP HPLC equipped with a Shimadzu SPD-M10AVP diode array detector and a Waters Acquity UPC2 system with a PDA detector and a QDA mass detector.

\section{Enantioselective Enolate Trapping; General Procedure A}

In a heat-dried Schlenk tube equipped with a septum and a magnetic stir bar, $\mathrm{CuBr} \cdot \mathrm{SMe}_{2}$ (0.05 equiv) and the ligand $\left(R_{c}, S_{p}\right)$-Revjosiphos (L1) ( 0.06 equiv) were dissolved in DCM ( $1 \mathrm{~mL} / 0.1 \mathrm{mmol}$ of substrate) and stirred under a nitrogen atmosphere for $15 \mathrm{~min}$. The substrate (1.0 equiv) was added in one portion. After stirring for $5 \mathrm{~min}$ at room temperature, the mixture was cooled to $-78{ }^{\circ} \mathrm{C}$ and $\mathrm{BF}_{3} \cdot \mathrm{OEt}_{2}(1.2$ equiv) was added. After $5 \mathrm{~min}$, the trapping agent (4.0 equiv) was added followed by EtMgBr (1.5 equiv). After stirring at $-78^{\circ} \mathrm{C}$ for $3 \mathrm{~h}$, the reaction was quenched with $\mathrm{MeOH}(1 \mathrm{~mL})$ followed by saturated aqueous $\mathrm{NH}_{4} \mathrm{Cl}$ solution ( $1 \mathrm{~mL}$ ) and warmed to R.T. The reaction mixture was extracted with DCM $(3 \times 10 \mathrm{~mL})$. The combined organic phases were dried over $\mathrm{MgSO}_{4}$, filtered and the solvents removed on a rotary evaporator. The oily crude residue was purified by flash column chromatography using a mixture of pentane and EtOAc as eluent.

\section{Racemic Enolate Trapping; General Procedure B}

In a heat-dried Schlenk tube equipped with a septum and a magnetic stir bar, $\mathrm{CuBr} \cdot \mathrm{SMe}_{2}$ ( 0.05 equiv) and the ligand ( \pm )-BINAP ( 0.06 equiv) were dissolved in DCM ( $1 \mathrm{~mL} / 0.1 \mathrm{mmol}$ of substrate) and stirred under a nitrogen atmosphere for $15 \mathrm{~min}$. The substrate (1.0 equiv) was added in one portion. After stirring for $5 \mathrm{~min}$ at room temperature, the mixture was cooled to $-78{ }^{\circ} \mathrm{C}$ and $\mathrm{BF}_{3} \cdot \mathrm{OEt}_{2}$ (1.2 equiv) was added. After $5 \mathrm{~min}$, the trapping agent ( 4.0 equiv) was added followed by EtMgBr ( 1.5 equiv). After stirring at $-78^{\circ} \mathrm{C}$ for $3 \mathrm{~h}$, the reaction was quenched with $\mathrm{MeOH}(1 \mathrm{~mL})$ followed by saturated aqueous $\mathrm{NH}_{4} \mathrm{Cl}$ solution ( $1 \mathrm{~mL}$ ) and warmed to R.T. The reaction mixture was extracted with DCM $(3 \times 10 \mathrm{~mL})$. The combined organic phases were dried over $\mathrm{MgSO}_{4}$, filtered and the solvents removed on a rotary evaporator. The oily crude residue was purified by flash column chromatography using a mixture of pentane and EtOAc as eluent.

\section{(E)-2-(Prop-1-en-1-yl)benzoxazole (1a)}

Compound 1a was prepared according to the literature procedure. ${ }^{6}$ The product was obtained as a pale yellow solid after silica gel column chromatography (pentane/EtOAc, 95:5, v/v). Yield $=78 \%$. The NMR data are in agreement with those presented in the literature. ${ }^{6}$

${ }^{1} \mathrm{H} \mathrm{NMR}\left(400 \mathrm{MHz}, \mathrm{CDCl}_{3}\right): \delta=7.75-7.59(\mathrm{~m}, 1 \mathrm{H}), 7.55-7.40(\mathrm{~m}, 1 \mathrm{H})$, 7.35-7.20 (m, $2 \mathrm{H}), 7.04$ (dq, $J=15.9,6.9 \mathrm{~Hz}, 1 \mathrm{H}), 6.46$ (dq, $J=15.9$, $1.8 \mathrm{~Hz}, 1 \mathrm{H}), 2.02(\mathrm{dd}, J=6.9,1.8 \mathrm{~Hz}, 3 \mathrm{H})$.

${ }^{13} \mathrm{C}$ NMR $\left(101 \mathrm{MHz}, \mathrm{CDCl}_{3}\right): \delta=162.3,150.1,141.9,139.0,124.7$, 124.2, 119.7, 118.2, 110.1, 18.7 .

\section{(E)-2-Styrylbenzoxazole (1b)}

Compound 1b was prepared according to the literature procedure.[11] The product was obtained as a white solid after crystallization from $\mathrm{MeOH}$. Yield $=65 \%$. The NMR data are in agreement with those presented in the literature. ${ }^{11}$

${ }^{1} \mathrm{H} \mathrm{NMR}\left(400 \mathrm{MHz}, \mathrm{CDCl}_{3}\right): \delta=7.74(\mathrm{~d}, J=16.3 \mathrm{~Hz}, 1 \mathrm{H}), 7.68-7.64(\mathrm{~m}$, $1 \mathrm{H})$, 7.54-7.51 (m, $2 \mathrm{H}), 7.51-7.45$ (m, $1 \mathrm{H}), 7.39-7.25$ (m, $5 \mathrm{H}), 7.02$ (d, $J=16.3 \mathrm{~Hz}, 1 \mathrm{H})$.

${ }^{13} \mathrm{C}$ NMR $\left(101 \mathrm{MHz}, \mathrm{CDCl}_{3}\right): \delta=166.9,153.8,137.6,135.3,134.3$, $129.4,128.9,128.5,127.4,126.3,125.3,122.9,122.1,121.5$.

\section{(E)-2-Styrylbenzothiazole (1c)}

Compound 1c was prepared according to the literature procedure. ${ }^{6}$ The product was obtained as a white solid after crystallization from $\mathrm{MeOH}$. Yield $=46 \%$. The NMR data are in agreement with those presented in the literature. ${ }^{6}$

${ }^{1} \mathrm{H}$ NMR $\left(400 \mathrm{MHz}, \mathrm{CDCl}_{3}\right): \delta=8.01(\mathrm{~d}, J=8.2 \mathrm{~Hz}, 1 \mathrm{H}), 7.87(\mathrm{~d}, J=7.7$ $\mathrm{Hz}, 1 \mathrm{H}), 7.62-7.57(\mathrm{~m}, 2 \mathrm{H}), 7.54(\mathrm{~d}, J=16.2 \mathrm{~Hz}, 1 \mathrm{H}), 7.48$ (ddd, $J=$ 8.3, 7.2, $1.3 \mathrm{~Hz}, 1 \mathrm{H}), 7.45-7.34(\mathrm{~m}, 5 \mathrm{H})$.

${ }^{13} \mathrm{C}$ NMR (101 MHz, $\left.\mathrm{CDCl}_{3}\right): \delta=137.7,129.4,128.9,127.4,126.3$, $125.3,122.9,122.1,121.5$.

\section{(E)-2-(Pent-1-en-1-yl)benzothiazole (1d)}

Compound 1d was prepared according to the literature procedure. ${ }^{6}$ The product was obtained as an orange-yellow solid after silica gel flash column chromatography (pentane/EtOAc, 95:5, v/v). Yield $=71 \%$. The NMR data are in agreement with those presented in the literature. $^{6}$

${ }^{1} \mathrm{H} \mathrm{NMR}\left(400 \mathrm{MHz}, \mathrm{CDCl}_{3}\right): \delta=7.93(\mathrm{~d}, J=8.1 \mathrm{~Hz}, 1 \mathrm{H}), 7.75(\mathrm{~d}, J=9.3$ $\mathrm{Hz}, 1 \mathrm{H}), 7.39$ (td, $J=8.3,7.2,1.3 \mathrm{~Hz}, 1 \mathrm{H}), 7.32-7.24(\mathrm{~m}, 1 \mathrm{H}), 6.80-$ $6.63(\mathrm{~m}, 2 \mathrm{H}), 2.28-2.13(\mathrm{~m}, 2 \mathrm{H}), 1.52(\mathrm{sext}, J=7.4 \mathrm{~Hz}, 2 \mathrm{H}), 0.95(\mathrm{t}, J=$ $7.4 \mathrm{~Hz}, 3 \mathrm{H})$.

${ }^{13} \mathrm{C}$ NMR $\left(101 \mathrm{MHz}, \mathrm{CDCl}_{3}\right): \delta=167.3,153.5,141.7,133.9,125.9$, 124.9, 124.6, 122.6, 121.2, 34.8, 21.6, 13.6.

\section{(E)-4,5-Diphenyl-2-(prop-1-en-1-yl)oxazole (1e)}

Compound 1e was prepared according to the literature procedure. ${ }^{6}$ The product was obtained as a pale yellow solid after silica gel flash column chromatography (pentane/EtOAc, 95:5, v/v). Yield $=66 \%$. The NMR data are in agreement with those presented in the literature. ${ }^{6}$

${ }^{1} \mathrm{H} \mathrm{NMR}\left(400 \mathrm{MHz}, \mathrm{CDCl}_{3}\right): \delta=7.81-7.67(\mathrm{~m}, 2 \mathrm{H}), 7.67-7.56(\mathrm{~m}, 2 \mathrm{H})$, 7.49-7.21 (m, $6 \mathrm{H}), 6.85$ (dq, $J=15.8,6.9 \mathrm{~Hz}, 1 \mathrm{H}), 6.41(\mathrm{~d}, J=15.8 \mathrm{~Hz}$, $1 \mathrm{H}), 1.96(\mathrm{dd}, J=6.9,1.8 \mathrm{~Hz}, 3 \mathrm{H})$.

${ }^{13} \mathrm{C}$ NMR $\left(101 \mathrm{MHz}, \mathrm{CDCl}_{3}\right): \delta=159.8,144.6,136.1,135.4,132.6$, 129.0, 128.6, 128.5, 128.4, 128.1, 128.0, 126.5, 117.8, 18.6.

\section{(E)-4-Styrylpyridine (1f)}

To a heated solution of DMF, $\mathrm{KOH}\left(60^{\circ} \mathrm{C}\right)$ and $\gamma$-picoline $(50 \mathrm{mmol}, 1$ equiv) was added dropwise benzaldehyde ( $25 \mathrm{mmol}, 0.5$ equiv). The reaction mixture was heated to $160{ }^{\circ} \mathrm{C}$. After $16 \mathrm{~h}$, the mixture was cooled to room temperature and diluted with $\mathrm{H}_{2} \mathrm{O}$. The mixture was extracted with DCM $(3 \times 20 \mathrm{~mL})$. The combined organic phase was washed with $\mathrm{H}_{2} \mathrm{O}(6 \times 15 \mathrm{~mL})$, dried over $\mathrm{MgSO}_{4}$ and the volatiles removed under reduced pressure. The residue was purified by flash chromatography (pentane/EtOAc, 80:20) to afford pure product $\mathbf{1 f}$ as a white solid. Yield $=63 \%$. The NMR data are in agreement with those presented in the literature. ${ }^{12}$ 
${ }^{1} \mathrm{H}$ NMR $\left(400 \mathrm{MHz}, \mathrm{CDCl}_{3}\right): \delta=8.58(\mathrm{~d}, J=5.1 \mathrm{~Hz}, 2 \mathrm{H}), 7.55(\mathrm{~d}, J=7.0$ $\mathrm{Hz}, 2 \mathrm{H}$ ), 7.44-7.34 (m, $5 \mathrm{H}$ ), 7.31 (d, $J=16.0 \mathrm{~Hz}, 1 \mathrm{H}), 7.02$ (d, $J=16.3$ $\mathrm{Hz}, 1 \mathrm{H})$.

${ }^{13} \mathrm{C}$ NMR $\left(101 \mathrm{MHz}, \mathrm{CDCl}_{3}\right): \delta=150.3,144.8,136.3,133.3,129.0$, 128.9, 127.2, 126.1, 121.0 .

HRMS $\left(\mathrm{ESI}^{+}\right): m / z[\mathrm{M}+\mathrm{H}]^{+}$calcd for $\mathrm{C}_{13} \mathrm{H}_{12} \mathrm{~N}$ : 182.09643; found: 182.09655.

(E)-2-(3-Phenylprop-1-en-1-yl)-5-(trifluoromethyl)pyridine (1g) Compound $\mathbf{1 g}$ was prepared according to the literature procedure. ${ }^{6}$ The product was obtained as a pale yellow liquid after silica gel flash column chromatography (pentane/EtOAc, 95:5, v/v). Yield $=50 \%$.

${ }^{1} \mathrm{H}$ NMR $\left(400 \mathrm{MHz}, \mathrm{CDCl}_{3}\right): \delta=8.84(\mathrm{~s}, 1 \mathrm{H}), 7.85$ (dd, $J=8.3,2.2 \mathrm{~Hz}, 1$ H), 7.53-7.27 (m, $5 \mathrm{H}), 7.24(\mathrm{q}, J=7.3,1 \mathrm{H}), 6.57(\mathrm{~d}, J=15.9 \mathrm{~Hz}, 1 \mathrm{H})$, $6.43(\mathrm{dt}, J=15.7,6.9 \mathrm{~Hz}, 1 \mathrm{H}), 3.82(\mathrm{~d}, J=6.9 \mathrm{~Hz}, 2 \mathrm{H})$.

${ }^{13} \mathrm{C}$ NMR (101 MHz, $\mathrm{CDCl}_{3}$ ): $\delta=164.4,146.5$ (q, $J=3.9 \mathrm{~Hz}$ ), 137.1, $133.7(\mathrm{q}, J=3.5 \mathrm{~Hz}), 132.9,128.7,127.6,126.4,126.2,122.7,42.0$.

\section{(E)-2-Styrylquinoline (1h)}

Compound $\mathbf{1 h}$ was prepared according to the literature procedure. ${ }^{6}$ The product was obtained as a white solid after silica gel flash column chromatography (pentane/EtOAc, 95:5, v/v). Yield $=91 \%$. The NMR data are in agreement with those presented in the literature. ${ }^{6}$

${ }^{1} \mathrm{H} \mathrm{NMR}\left(400 \mathrm{MHz}, \mathrm{CDCl}_{3}\right): \delta=8.13(\mathrm{~d}, J=8.6 \mathrm{~Hz}, 1 \mathrm{H}), 8.09$ (d, $J=9.3$ $\mathrm{Hz}, 1 \mathrm{H}$ ), 7.78 (dd, $J=8.1,1.4 \mathrm{~Hz}, 1 \mathrm{H}), 7.74-7.61(\mathrm{~m}, 5 \mathrm{H}), 7.50$ (ddd, $J=8.1,6.9,1.2 \mathrm{~Hz}, 1 \mathrm{H}), 7.45-7.36(\mathrm{~m}, 3 \mathrm{H}), 7.36-7.28(\mathrm{~m}, 1 \mathrm{H})$.

${ }^{13} \mathrm{C}$ NMR $\left(101 \mathrm{MHz}, \mathrm{CDCl}_{3}\right): \delta=156.3,148.6,136.9,136.7,134.8$, $130.1,129.5,129.3,129.1,129.0,127.8,127.7,127.6,126.5,119.6$.

\section{(E)-2-(3-Phenylprop-1-en-1-yl)quinoline (1i)}

Compound $\mathbf{1 h}$ was prepared according to the literature procedure. ${ }^{6}$ The product was obtained as a colorless oil after silica gel flash column chromatography (pentane/EtOAc, 95:5, v/v). Yield $=76 \%$.

${ }^{1} \mathrm{H}$ NMR $\left(400 \mathrm{MHz}, \mathrm{CDCl}_{3}\right.$ ): $\delta=8.04(\mathrm{dd}, J=8.1,2.8 \mathrm{~Hz}, 2 \mathrm{H}), 7.74(\mathrm{dd}$, $J=8.1,1.4 \mathrm{~Hz}, 1 \mathrm{H}), 7.68(\mathrm{ddd}, J=8.5,6.9,1.5 \mathrm{~Hz}, 1 \mathrm{H}), 7.51(\mathrm{~d}, J=8.6$ $\mathrm{Hz}, 1 \mathrm{H}$ ), 7.47 (ddd, $J=8.1,6.9,1.2 \mathrm{~Hz}, 1 \mathrm{H}), 7.38-7.21(\mathrm{~m}, 5 \mathrm{H}), 6.96$ $(\mathrm{dt}, J=15.9,6.8 \mathrm{~Hz}, 1 \mathrm{H}), 6.78(\mathrm{dt}, J=15.8,1.5 \mathrm{~Hz}, 1 \mathrm{H}), 3.67(\mathrm{~d}, J=6.8$ $\mathrm{Hz}, 2 \mathrm{H})$.

${ }^{13} \mathrm{C}$ NMR $\left(101 \mathrm{MHz}, \mathrm{CDCl}_{3}\right): \delta=156.0,148.0,139.2,136.1,136.0$, 132.1, 129.5, 129.1, 128.8, 128.5, 127.4, 127.1, 126.3, 125.9, 118.7, 39.4.

HRMS $\left(\mathrm{ESI}^{+}\right): m / z[\mathrm{M}+\mathrm{H}]^{+}$calcd for $\mathrm{C}_{18} \mathrm{H}_{16} \mathrm{~N}$ : 246.12790; found: 246.12773.

\section{(E)-2-(Oct-1-en-1-yl)quinolone (1j)}

Compound $\mathbf{1} \mathbf{j}$ was prepared according to the literature procedure. ${ }^{6}$ The product was obtained as a colorless oil after silica gel flash column chromatography (pentane/EtOAc, 95:5, v/v). Yield $=91 \%$. The NMR data are in agreement with those presented in the literature. ${ }^{6}$

$\left.{ }^{1} \mathrm{H} \mathrm{NMR} \mathrm{(400} \mathrm{MHz,} \mathrm{CDCl}_{3}\right): \delta=8.10-7.95(\mathrm{~m}, 2 \mathrm{H}), 7.76-7.59(\mathrm{~m}, 2 \mathrm{H})$, 7.55-7.34 (m, $2 \mathrm{H}), 6.90-6.76(\mathrm{~m}, 1 \mathrm{H}), 6.70(\mathrm{~d}, J=15.9 \mathrm{~Hz}, 1 \mathrm{H}), 2.30$ (q, $J=7.2 \mathrm{~Hz}, 2 \mathrm{H}$ ), 1.52 (quin, $J=7.3 \mathrm{~Hz}, 2 \mathrm{H}$ ), 1.42-1.19 (m, $6 \mathrm{H}$ ), $0.97-0.79(\mathrm{~m}, 3 \mathrm{H})$.

${ }^{13} \mathrm{C}$ NMR $\left(101 \mathrm{MHz}, \mathrm{CDCl}_{3}\right): \delta=156.5,148.0,138.0,136.1,131.0$, 129.5, 129.1, 127.4, 127.1, 125.8, 118.7, 33.1, 31.7, 29.0, 28.9, 22.6, 14.1.

\section{(E)-2-(Oct-1-en-1-yl)pyrimidine (1k)}

Compound $1 \mathbf{k}$ was prepared according to the literature procedure. ${ }^{13}$ The product was obtained as a colorless oil after silica gel flash column chromatography (pentane/EtOAc, 95:5, v/v).

${ }^{1} \mathrm{H}$ NMR (400 MHz, $\mathrm{CDCl}_{3}$ ): $\delta=8.65(\mathrm{~d}, J=4.9 \mathrm{~Hz}, 2 \mathrm{H}), 7.17(\mathrm{dt}, J=$ 15.6, 7.0 Hz, $1 \mathrm{H}), 7.05$ (t, $J=4.9 \mathrm{~Hz}, 1 \mathrm{H}), 6.55(\mathrm{dt}, J=15.6,1.5 \mathrm{~Hz}, 1 \mathrm{H})$, 2.30 (qd, $J=7.2,1.6 \mathrm{~Hz}, 2 \mathrm{H}), 1.57-1.44(\mathrm{~m}, 2 \mathrm{H}), 1.42-1.20(\mathrm{~m}, 6 \mathrm{H})$, $0.93-0.79(\mathrm{~m}, 3 \mathrm{H})$.

${ }^{13} \mathrm{C}$ NMR $\left(101 \mathrm{MHz}, \mathrm{CDCl}_{3}\right): \delta=164.8,156.9,142.5,129.4,118.3,32.7$, $31.7,28.9,28.6,22.6,14.1$.

\section{(E)-2,4-Dimethoxy-6-(oct-1-en-1-yl)-1,3,5-triazine (11)}

Compound $\mathbf{1 1}$ was prepared according to the literature procedure. ${ }^{13}$ The product was obtained as a colorless oil after silica gel flash column chromatography (pentane/EtOAc, 95:5, v/v).

${ }^{1} \mathrm{H}$ NMR $\left(400 \mathrm{MHz}, \mathrm{CDCl}_{3}\right): \delta=7.36(\mathrm{dt}, J=15.5,7.0 \mathrm{~Hz}, 1 \mathrm{H}), 6.27(\mathrm{~d}$, $J=15.5 \mathrm{~Hz}, 1 \mathrm{H}$ ), $3.98(\mathrm{~s}, 6 \mathrm{H}$ ), 2.29-2.18 (m, $2 \mathrm{H}$ ), 1.45 (quin, $J=7.2$ $\mathrm{Hz}, 2 \mathrm{H}), 1.35-1.15$ (m, $6 \mathrm{H}), 0.87-0.76$ (m, $3 \mathrm{H})$.

${ }^{13} \mathrm{C}$ NMR $\left(101 \mathrm{MHz}, \mathrm{CDCl}_{3}\right): \delta=174.8,172.5,147.7,127.8,54.9,32.7$, 31.6, 28.9, 28.2, 22.5, 14.0.

HRMS $\left(\right.$ ESI $\left.^{+}\right): m / z[M+H]^{+}$calcd for $\mathrm{C}_{13} \mathrm{H}_{21} \mathrm{~N}_{3} \mathrm{O}_{2}: 252.17065$; found: 252.17052 .

\section{(E)-4,4,5,5-Tetramethyl-2-styryl-1,3,2-dioxaborolane (8)}

Compound $\mathbf{8}$ was synthesized according to the literature procedure. ${ }^{14}$ The product was isolated as a colorless oil after flash column chromatography (pentane/EtOAc, 99:1, v/v). Yield $=87 \%$.

${ }^{1} \mathrm{H}$ NMR $\left(400 \mathrm{MHz}, \mathrm{CDCl}_{3}\right): \delta=7.51-7.47(\mathrm{~m}, 2 \mathrm{H}), 7.40(\mathrm{~d}, J=18.5 \mathrm{~Hz}$, $1 \mathrm{H}), 7.36-7.28$ (m, $3 \mathrm{H}), 6.17$ (d, J = $18.5 \mathrm{~Hz}, 1 \mathrm{H}), 1.32(\mathrm{~s}, 12 \mathrm{H})$.

${ }^{13} \mathrm{C} \mathrm{NMR}\left(101 \mathrm{MHz}, \mathrm{CDCl}_{3}\right): \delta=152.1,140.1,131.5,131.2,129.7,86.0$, 27.5.

HRMS $\left(\mathrm{ESI}^{+}\right): m / z[\mathrm{M}+\mathrm{H}]^{+}$calcd for $\mathrm{C}_{14} \mathrm{H}_{20} \mathrm{BO}_{2}: 231.15509$; found: 231.15324.

(E)-4,4,5,5-Tetramethyl-2-(oct-1-en-1-yl)-1,3,2-dioxaborolane (9) Compound $\mathbf{9}$ was synthesized according to the literature procedure. ${ }^{14}$ The product was isolated as a colorless oil after flash column chromatography (pentane/EtOAc, 99:1, v/v). Yield = 72\%. The NMR data are in agreement with those presented in the literature.

$\left.{ }^{1} \mathrm{H} \mathrm{NMR} \mathrm{(400} \mathrm{MHz,} \mathrm{CDCl} 3\right): \delta=6.63(\mathrm{dt}, J=18.0,6.4 \mathrm{~Hz}, 1 \mathrm{H}), 5.42(\mathrm{dt}$, $J=18.0,1.6 \mathrm{~Hz}, 1 \mathrm{H}), 2.19-2.06(\mathrm{~m}, 2 \mathrm{H}), 1.45-1.35(\mathrm{~m}, 2 \mathrm{H}), 1.26(\mathrm{~s}$, $18 \mathrm{H}), 0.98-0.76(\mathrm{~m}, 3 \mathrm{H})$.

${ }^{13} \mathrm{C}$ NMR $\left(101 \mathrm{MHz}, \mathrm{CDCl}_{3}\right): \delta=154.8,82.9,35.8,31.7,28.9,28.2,24.7$, 22.6, 14.1 .

\section{(E)-4,4,5,5-Tetramethyl-2-(3-phenylprop-1-en-1-yl)-1,3,2-dioxa- borolane (10)}

Compound $\mathbf{1 0}$ was synthesized according to the literature procedure. ${ }^{14}$ The product was isolated as a colorless oil after flash column chromatography (pentane/EtOAc, 99:1, v/v). Yield $=53 \%$.

${ }^{1} \mathrm{H} \mathrm{NMR}\left(400 \mathrm{MHz}, \mathrm{CDCl}_{3}\right): \delta=7.37-7.26(\mathrm{~m}, 2 \mathrm{H}), 7.23-7.15(\mathrm{~m}, 3 \mathrm{H})$, $6.78(\mathrm{dt}, J=17.8,6.3 \mathrm{~Hz}, 1 \mathrm{H}), 5.47(\mathrm{dt}, J=17.8,1.6 \mathrm{~Hz}, 1 \mathrm{H}), 3.49$ (dd, $J=6.3,1.6 \mathrm{~Hz}, 2 \mathrm{H}), 1.26(\mathrm{~s}, 12 \mathrm{H})$.

${ }^{13} \mathrm{C}$ NMR $\left(101 \mathrm{MHz}, \mathrm{CDCl}_{3}\right): \delta=152.3,138.9,128.8,128.3,126.0,82.9$, 42.1, 24.7.

HRMS $\left(\mathrm{ESI}^{+}\right): m / z[\mathrm{M}+\mathrm{H}]^{+}$calcd for $\mathrm{C}_{15} \mathrm{H}_{22} \mathrm{BO}_{2}: 245.17074$; found: 245.17078 . 


\section{(E)-N-(2-Bromophenyl)but-2-enamide (11)}

Compound 11 was synthesized according to the literature procedure. ${ }^{15}$ The product was isolated as a yellow oil after flash column chromatography (pentane/EtOAc, 95:5, v/v). Yield $=78 \%$. The NMR data are in agreement with those presented in the literature. ${ }^{6}$

${ }^{1} \mathrm{H} \mathrm{NMR}\left(400 \mathrm{MHz}, \mathrm{CDCl}_{3}\right): \delta=8.44(\mathrm{~d}, J=8.3 \mathrm{~Hz}, 1 \mathrm{H}), 7.54(\mathrm{dd}, J=8.1$, $1.5 \mathrm{~Hz}, 1 \mathrm{H}$ ), 7.39-7.27 (m, $1 \mathrm{H}), 7.10-6.90$ (m, $2 \mathrm{H}$ ), 6.01 (dq, $J=15.1$, $1.7 \mathrm{~Hz}, 1 \mathrm{H}), 1.95$ (dd, $J=6.9,1.7 \mathrm{~Hz}, 3 \mathrm{H}$ ).

${ }^{13} \mathrm{C}$ NMR $\left(101 \mathrm{MHz}, \mathrm{CDCl}_{3}\right): \delta=163.8,142.1,135.8,132.2,128.33$, $128.32,125.4,125.0,122.0,17.9$.

\section{Ethyl (3S,4R,5S)-4-(Benzoxazol-2-yl)-3-methyl-5-phenylhepta- noate (4d)}

Compound 4d was synthesized following general procedure $A$ with of 1 b $(0.1 \mathrm{mmol}), \mathrm{BF}_{3} \cdot \mathrm{OEt}_{2}$ ( $0.12 \mathrm{mmol}, 1.2$ equiv), $\mathrm{EtMgBr}\left(3 \mathrm{M}\right.$ in $\mathrm{Et}_{2} \mathrm{O}$, $0.15 \mathrm{mmol}, 1.5$ equiv), $\mathrm{CuBr} \cdot \mathrm{SMe}_{2}(0.005 \mathrm{mmol}, 5 \mathrm{~mol} \%)$, ligand $\left(R_{c}, S_{p}\right)$-L1 (0.006 mmol, $\left.6 \mathrm{~mol} \%\right)$, and 3d ( $0.4 \mathrm{mmol}, 4$ equiv) in DCM $(1 \mathrm{~mL})$. Product $4 d$ was obtained as a pale yellow oil after flash column chromatography $\left(\mathrm{SiO}_{2}\right.$, pentane/EtOAc, 97:3, v/v).

Yield: $24.8 \mathrm{mg}(68 \%) ; 97 \%$ ee.

${ }^{1} \mathrm{H}$ NMR $\left(400 \mathrm{MHz}, \mathrm{CDCl}_{3}\right.$ ): $\delta=7.75(\mathrm{dd}, J=6.3,3.0 \mathrm{~Hz}, 1 \mathrm{H}), 7.55$ (dd, $J=6.4,2.9 \mathrm{~Hz}, 1 \mathrm{H}$ ), 7.41-7.32 (m, $4 \mathrm{H}$ ), 7.30-7.23 (m, $3 \mathrm{H}$ ), 4.09 (qt, $J=$ 7.1, 3.7 Hz, $2 \mathrm{H}$ ), 3.57 (dd, $J=11.6,3.6 \mathrm{~Hz}, 1 \mathrm{H}), 3.19(\mathrm{td}, J=11.0,3.6$ $\mathrm{Hz}, 1 \mathrm{H}), 2.26-2.05(\mathrm{~m}, 2 \mathrm{H}), 1.93(\mathrm{dd}, J=15.1,6.5 \mathrm{~Hz}, 1 \mathrm{H}), 1.51-1.32$ $(\mathrm{m}, 2 \mathrm{H}), 1.21(\mathrm{t}, J=7.1 \mathrm{~Hz}, 3 \mathrm{H}), 0.97(\mathrm{~d}, J=6.7 \mathrm{~Hz}, 3 \mathrm{H}), 0.60$ (t, $J=7.3$ $\mathrm{Hz}, 3 \mathrm{H})$.

${ }^{13} \mathrm{C}$ NMR $\left(101 \mathrm{MHz}, \mathrm{CDCl}_{3}\right): \delta=172.4,167.3,150.6,141.8,141.3$, 128.7, 128.4, 126.9, 124.7, 124.4, 120.0, 110.7, 60.4, 49.2, 48.5, 40.3, $30.8,28.9,14.6,14.3,12.0$.

HRMS $\left(\mathrm{ESI}^{+}\right): m / z[\mathrm{M}+\mathrm{H}]^{+}$calcd for $\mathrm{C}_{23} \mathrm{H}_{28} \mathrm{NO}_{3}$ : 366.20689; found: 366.20637

CSP-HPLC (206 nm, Chiralcel OD-H, $n$-heptane $/$ PrOH $=95: 5,40^{\circ} \mathrm{C}$, $0.5 \mathrm{~mL} / \mathrm{min}$ ): $t_{\mathrm{R}}=7.99 \mathrm{~min}$ (major), $t_{\mathrm{R}}=13.02 \mathrm{~min}$ (minor).

\section{Ethyl (3S,4S,5S)-4-(Benzoxazol-2-yl)-3,5-diphenylheptanoate (4e)}

Compound $\mathbf{4 e}$ was synthesized following general procedure $\mathrm{A}$ with $0.1 \mathrm{mmol}$ of $\mathbf{1 b}(0.1 \mathrm{mmol}), \mathrm{BF}_{3} \cdot \mathrm{OEt}_{2}(0.12 \mathrm{mmol}, 1.2$ equiv), $\mathrm{EtMgBr}$

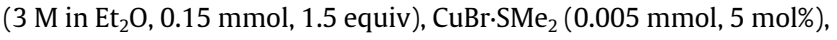
ligand $\left(R, S_{p}\right)$-L1 $(0.006 \mathrm{mmol}, 6 \mathrm{~mol} \%)$, and $3 \mathbf{e}(0.4 \mathrm{mmol}, 4$ equiv) in DCM $(1 \mathrm{~mL})$. Product $4 \mathbf{e}$ was obtained as a pale yellow oil after flash column chromatography $\left(\mathrm{SiO}_{2}\right.$, pentane/EtOAc, $\left.97: 3, \mathrm{v} / \mathrm{v}\right)$.

Yield: $20.9 \mathrm{mg}$ (49\%); 91\% ee.

${ }^{1} \mathrm{H}$ NMR $\left(400 \mathrm{MHz}, \mathrm{CDCl}_{3}\right): \delta=7.73(\mathrm{~d}, J=6.5 \mathrm{~Hz}, 1 \mathrm{H}), 7.40(\mathrm{t}, J=7.6$ $\mathrm{Hz}, 3 \mathrm{H}), 7.38-7.26(\mathrm{~m}, 2 \mathrm{H}), 7.25(\mathrm{~d}, J=7.3 \mathrm{~Hz}, 3 \mathrm{H}), 7.10(\mathrm{dt}, J=14.4$, $7.0 \mathrm{~Hz}, 3 \mathrm{H}$ ), 6.65 (d, $J=7.4 \mathrm{~Hz}, 2 \mathrm{H}$ ), 4.00 (dddd, $J=17.8,10.7,7.1,3.6$ $\mathrm{Hz}, 2 \mathrm{H}$ ), 3.91 (dd, $J=11.2,4.4 \mathrm{~Hz}, 1 \mathrm{H}), 3.50$ (td, $J=7.7,4.4 \mathrm{~Hz}, 1 \mathrm{H}$ ), $2.99(\mathrm{td}, J=10.6,4.0 \mathrm{~Hz}, 1 \mathrm{H}), 2.88(\mathrm{dd}, J=16.0,7.9 \mathrm{~Hz}, 1 \mathrm{H}), 2.57$ (dd, $J=15.9,7.8 \mathrm{~Hz}, 1 \mathrm{H}), 1.54-1.35$ (m, $2 \mathrm{H}), 1.09$ (t, $J=7.1 \mathrm{~Hz}, 3 \mathrm{H}), 0.56$ (t, $J=7.3 \mathrm{~Hz}, 3 \mathrm{H}$ ).

${ }^{13} \mathrm{C}$ NMR $\left(101 \mathrm{MHz}, \mathrm{CDCl}_{3}\right): \delta=171.7,166.3,150.4,141.8,141.0$, 139.4, 128.9, 128.8, 128.6, 127.7, 127.0, 126.8, 124.7, 124.2, 119.9, $110.5,60.3,49.7,48.0,42.4,39.0,28.4,14.0,11.5$.

HRMS $\left(\mathrm{ESI}^{+}\right): m / z[\mathrm{M}+\mathrm{H}]^{+}$calcd for $\mathrm{C}_{28} \mathrm{H}_{30} \mathrm{NO}_{3}$ : 428.22202; found: 428.22157.

CSP-HPLC (233 nm, Chiralcel OD-H, $n$-heptane $/ \mathrm{iPrOH}=95: 5,40^{\circ} \mathrm{C}$, $0.5 \mathrm{~mL} / \mathrm{min}$ ): $t_{\mathrm{R}}=8.51 \mathrm{~min}$ (major), $t_{\mathrm{R}}=9.23 \mathrm{~min}$ (minor).

\section{(3S,4S)-3-(Benzooxazol-2-yl)-2,4-diphenylhexan-2-ol (4l)}

Compound $\mathbf{4 1}$ was synthesized following general procedure $A$ with $\mathbf{1 b}$ (0.1 mmol), $\mathrm{BF}_{3} \cdot \mathrm{OEt}_{2}$ (0.12 mmol, 1.2 equiv), $\operatorname{EtMgBr}\left(3 \mathrm{M}_{\text {in }} \mathrm{Et}_{2} \mathrm{O}, 0.15\right.$ mmol, 1.5 equiv), $\mathrm{CuBr} \cdot \mathrm{SMe}_{2}(0.005 \mathrm{mmol}, 5 \mathrm{~mol} \%)$, ligand $\left(R, S_{p}\right)-\mathbf{L 1}$ (0.006 mmol, $6 \mathrm{~mol} \%)$, and 31 (0.4 mmol, 4 equiv) in DCM ( $1 \mathrm{~mL})$. Product $\mathbf{4 1}$ was obtained as a white solid after flash column chromatography $\left(\mathrm{SiO}_{2}\right.$, pentane/EtOAc, 97:3, v/v).

Yield: $14.8 \mathrm{mg}$ (40\%); $97 \%$ ee.

${ }^{1} \mathrm{H}$ NMR $\left(400 \mathrm{MHz}, \mathrm{CDCl}_{3}\right): \delta=7.47-7.30(\mathrm{~m}, 3 \mathrm{H}), 7.28-7.22(\mathrm{~m}, 1 \mathrm{H})$, 7.20-7.08 (m, $4 \mathrm{H}), 7.07-6.92(\mathrm{~m}, 6 \mathrm{H}), 4.79(\mathrm{~s}, 1 \mathrm{H}), 3.89(\mathrm{~d}, J=4.3 \mathrm{~Hz}$, $1 \mathrm{H}), 3.54-3.49(\mathrm{~m}, 1 \mathrm{H}), 2.19-2.02(\mathrm{~m}, 1 \mathrm{H}), 2.02-1.90(\mathrm{~m}, 1 \mathrm{H}), 1.78$ $(\mathrm{s}, 3 \mathrm{H}), 0.86(\mathrm{t}, J=7.3 \mathrm{~Hz}, 3 \mathrm{H})$.

${ }^{13} \mathrm{C}$ NMR $\left(101 \mathrm{MHz}, \mathrm{CDCl}_{3}\right): \delta=166.2,149.1,148.4,141.9,140.0$, 128.9, 128.0, 127.6, 126.4, 126.1, 124.5, 124.3, 123.9, 119.3, 110.0, 76.5, 54.7, 47.4, 30.0, 28.7, 12.6 .

HRMS $\left(\mathrm{ESI}^{+}\right): m / z[\mathrm{M}+\mathrm{H}]^{+}$calcd for $\mathrm{C}_{18} \mathrm{H}_{26} \mathrm{NO}_{3}$ : 372.1964; found: 372.1962.

CSP-HPLC (254 nm, Chiralcel OD-H, $n$-heptane $/ \mathrm{iPrOH}=99: 1,40^{\circ} \mathrm{C}$, $0.5 \mathrm{~mL} / \mathrm{min}$ ): $t_{\mathrm{R}}=10.26 \mathrm{~min}$ (minor), $t_{\mathrm{R}}=17.78 \mathrm{~min}$ (major).

(4S,5S)-4-(Benzooxazol-2-yl)-3-methyl-5-phenylheptan-3-ol (4m) Compound $\mathbf{4 m}$ was synthesized following general procedure $A$ with 1b $(0.1 \mathrm{mmol}), \mathrm{BF}_{3} \cdot \mathrm{OEt}_{2}$ (0.12 mmol, 1.2 equiv), $\mathrm{EtMgBr}$ (3 $\mathrm{M}$ in $\mathrm{Et}_{2} \mathrm{O}$, $0.15 \mathrm{mmol}, 1.5$ equiv), $\mathrm{CuBr} \cdot \mathrm{SMe}_{2}(0.005 \mathrm{mmol}, 5 \mathrm{~mol} \%)$, ligand $\left(R_{c}, S_{p}\right)$-L1 (0.006 mmol, $\left.6 \mathrm{~mol} \%\right)$, and $\mathbf{3 m}(0.4 \mathrm{mmol}, 4$ equiv) in DCM $(1 \mathrm{~mL})$. An inseparable mixture of isomers of product $4 \mathrm{~m}$ was obtained as a white solid after flash column chromatography $\left(\mathrm{SiO}_{2}\right.$, pentane/EtOAc, 97:3, v/v).

Yield: $16.8 \mathrm{mg}$ (52\%); $97 \%$ ee.

\section{Major Diastereoisomers}

${ }^{1} \mathrm{H} \mathrm{NMR}\left(400 \mathrm{MHz}, \mathrm{CDCl}_{3}\right): \delta=7.76-7.72(\mathrm{~m}, 1 \mathrm{H}), 7.55-7.50(\mathrm{~m}, 1 \mathrm{H})$, 7.39-7.27 (m, $4 \mathrm{H}), 7.27-7.19(\mathrm{~m}, 3 \mathrm{H}), 3.54(\mathrm{~d}, J=8.1 \mathrm{~Hz}, 1 \mathrm{H}), 3.30$ (dtd, $J=11.6,7.8,3.8 \mathrm{~Hz}, 1 \mathrm{H}), 1.61-1.28(\mathrm{~m}, 4 \mathrm{H}), 1.19(\mathrm{~s}, 3 \mathrm{H}), 0.78(\mathrm{t}$, $J=7.5 \mathrm{~Hz}, 3 \mathrm{H}), 0.56-0.52(\mathrm{~m}, 3 \mathrm{H})$.

${ }^{1} \mathrm{H} \mathrm{NMR}\left(400 \mathrm{MHz}, \mathrm{CDCl}_{3}\right): \delta=7.76-7.72(\mathrm{~m}, 1 \mathrm{H}), 7.55-7.50(\mathrm{~m}, 1 \mathrm{H})$, 7.39-7.27 (m, $4 \mathrm{H}), 7.27-7.19(\mathrm{~m}, 3 \mathrm{H}), 3.54(\mathrm{~d}, J=8.1 \mathrm{~Hz}, 1 \mathrm{H}), 3.30$ (dtd, $J=11.6,7.8,3.8 \mathrm{~Hz}, 1 \mathrm{H}), 1.61-1.28(\mathrm{~m}, 4 \mathrm{H}), 1.11(\mathrm{~s}, 3 \mathrm{H}), 0.78(\mathrm{t}$, $J=7.5 \mathrm{~Hz}, 3 \mathrm{H}), 0.56-0.52(\mathrm{~m}, 3 \mathrm{H})$.

${ }^{13} \mathrm{C}$ NMR $\left(101 \mathrm{MHz}, \mathrm{CDCl}_{3}\right): \delta=167.8,149.9,143.9,140.8,128.6$, 128.4, 126.6, 124.8, 124.4, 119.8, 110.6, 75.1, 54.3, 47.2, 34.7, 27.0, 25.4, 11.9, 8.2.

${ }^{13} \mathrm{C}$ NMR $\left(101 \mathrm{MHz}, \mathrm{CDCl}_{3}\right): \delta=167.6,149.8,143.4,140.7,128.7$, 128.5, 126.8, 124.8, 124.4, 119.8, 110.6, 75.2, 54.6, 47.2, 32.8, 27.1, 24.1, 11.9, 7.7.

\section{Minor Diastereoisomers}

${ }^{1} \mathrm{H}$ NMR $\left(400 \mathrm{MHz}, \mathrm{CDCl}_{3}\right): \delta=7.59-7.49(\mathrm{~m}, 1 \mathrm{H}), 7.41-7.35(\mathrm{~m}, 1 \mathrm{H})$, 7.25-7.23 (m, 2 H), 7.05-6.91 (m, $5 \mathrm{H}), 3.42(\mathrm{~d}, J=5.7 \mathrm{~Hz}, 1 \mathrm{H}), 3.39-$ $3.30(\mathrm{~m}, 1 \mathrm{H}), 2.18-2.02(\mathrm{~m}, 1 \mathrm{H}), 1.94-1.79(\mathrm{~m}, 2 \mathrm{H}), 1.79-1.63(\mathrm{~m}, 2$ H), $1.23(\mathrm{~s}, 2 \mathrm{H}), 1.01(\mathrm{t}, J=7.5 \mathrm{~Hz}, 3 \mathrm{H}), 0.77(\mathrm{t}, J=7.3 \mathrm{~Hz}, 3 \mathrm{H})$.

${ }^{1} \mathrm{H}$ NMR $\left(400 \mathrm{MHz}, \mathrm{CDCl}_{3}\right): \delta=7.59-7.49(\mathrm{~m}, 1 \mathrm{H}), 7.41-7.35(\mathrm{~m}, 1 \mathrm{H})$, 7.25-7.23 (m, 2 H), 7.05-6.91 (m, 5 H), 3.40 (d, J= 5.1 Hz, 1 H), 3.39$3.30(\mathrm{~m}, 1 \mathrm{H}), 2.18-2.02(\mathrm{~m}, 1 \mathrm{H}), 1.94-1.79(\mathrm{~m}, 2 \mathrm{H}), 1.79-1.63(\mathrm{~m}, 2$ H), $1.23(\mathrm{~s}, 2 \mathrm{H}), 0.88(\mathrm{t}, J=7.5 \mathrm{~Hz}, 3 \mathrm{H}), 0.80(\mathrm{t}, J=7.4 \mathrm{~Hz}, 3 \mathrm{H})$.

${ }^{13} \mathrm{C}$ NMR $\left(101 \mathrm{MHz}, \mathrm{CDCl}_{3}\right): \delta=166.8,149.7,142.1,140.4,128.8$, 127.7, 126.1, 124.5, 124.1, 119.6, 110.2, 74.9, 54.0, 47.5, 33.3, 29.2, $25.6,12.5,8.1$ 
${ }^{13} \mathrm{C}$ NMR $\left(101 \mathrm{MHz}, \mathrm{CDCl}_{3}\right): \delta=166.8,149.6,141.9,140.3,128.9$, 127.6, 126.1, 124.5, 124.1, 119.5, 110.2, 74.8, 53.9, 47.3, 34.9, 29.8, $24.2,12.5,8.5$.

CSP-HPLC (206 nm, Chiralpak OJ-H, $n$-heptane $/ \mathrm{iPrOH}=99.7: 0.3$, $40{ }^{\circ} \mathrm{C}, 0.5 \mathrm{~mL} / \mathrm{min}$ ): $t_{\mathrm{R}}=17.54,23.64 \mathrm{~min}$ (major), $t_{\mathrm{R}}=34.11,47.07$ $\min$ (minor).

Ethyl (3S,4S,5S)-4-(Benzoxazol-2-yl)-3,5-dimethylheptanoate (4n) Compound $4 \mathbf{n}$ was synthesized following general procedure A with 1a (0.1 mmol), $\mathrm{BF}_{3} \cdot \mathrm{OEt}_{2}\left(0.12 \mathrm{mmol}, 1.2\right.$ equiv), $\mathrm{EtMgBr}$ ( $3 \mathrm{M}$ in $\mathrm{Et}_{2} \mathrm{O}$, $0.15 \mathrm{mmol}, 1.5$ equiv), $\mathrm{CuBr} \cdot \mathrm{SMe}_{2}(0.005 \mathrm{mmol}, 5 \mathrm{~mol} \%)$, ligand $\left(R_{c}, S_{p}\right)$-L1 ( $\left.0.006 \mathrm{mmol}, 6 \mathrm{~mol} \%\right)$, and $3 \mathbf{d}(0.4 \mathrm{mmol}, 4$ equiv) in DCM $(1 \mathrm{~mL})$. Product $\mathbf{4 n}$ (an inseparable mixture of diastereoisomers) was obtained as a pale yellow oil after flash column chromatography $\left(\mathrm{SiO}_{2}\right.$, pentane/EtOAc, 97:3, v/v).

Yield: $16.1 \mathrm{mg}$ (53\%); 79\% ee.

${ }^{1} \mathrm{H}$ NMR (400 MHz, $\left.\mathrm{CDCl}_{3}\right)$ : $\delta$ (major diastereoisomer) $=7.72-7.67(\mathrm{~m}$, $1 \mathrm{H}), 7.52-7.46$ (m, $1 \mathrm{H}), 7.34-7.27$ ( $\mathrm{m}, 2 \mathrm{H}), 4.18-4.08$ (m, $2 \mathrm{H}), 2.90$ (dd, $J=9.7,5.4 \mathrm{~Hz}, 1 \mathrm{H}), 2.73-2.61(\mathrm{~m}, 1 \mathrm{H}), 2.37(\mathrm{dd}, J=15.6,5.6 \mathrm{~Hz}, 1$ H), 2.13-1.93 (m, $2 \mathrm{H}), 1.24(\mathrm{t}, J=7.2 \mathrm{~Hz}, 3 \mathrm{H}), 1.22-1.14(\mathrm{~m}, 2 \mathrm{H}), 1.03$ (dd, $J=9.4,6.7 \mathrm{~Hz}, 6 \mathrm{H}), 0.83(\mathrm{t}, J=7.4 \mathrm{~Hz}, 3 \mathrm{H}$ ).

${ }^{1} \mathrm{H}$ NMR $\left(400 \mathrm{MHz}, \mathrm{CDCl}_{3}\right): \delta$ (minor diastereoisomer $)=7.73-7.66(\mathrm{~m}$, $1 \mathrm{H}), 7.53-7.45$ ( $\mathrm{m}, 1 \mathrm{H}), 7.34-7.27$ ( $\mathrm{m}, 2 \mathrm{H}), 4.19-4.07$ ( $\mathrm{m}, 2 \mathrm{H}), 2.97$ $(\mathrm{t}, J=7.6 \mathrm{~Hz}, 1 \mathrm{H}), 2.73-2.61(\mathrm{~m}, 1 \mathrm{H}), 2.44(\mathrm{dd}, J=15.4,5.2 \mathrm{~Hz}, 1 \mathrm{H})$, 2.14-1.91 (m, 2 H), 1.59-1.47 (m, $1 \mathrm{H}), 1.37-1.24(\mathrm{~m}, 1 \mathrm{H}), 1.25(\mathrm{t}, J=$ $7.2 \mathrm{~Hz}, 3 \mathrm{H}), 0.97(\mathrm{~d}, J=6.8 \mathrm{~Hz}, 3 \mathrm{H}), 0.95(\mathrm{t}, J=7.4 \mathrm{~Hz}, 3 \mathrm{H}), 0.88(\mathrm{~d}, J=$ $6.7 \mathrm{~Hz}, 3 \mathrm{H})$.

${ }^{13} \mathrm{C}$ NMR $\left(101 \mathrm{MHz}, \mathrm{CDCl}_{3}\right): \delta=172.5,167.6,141.0,136.9,124.4$, 124.1, 119.7, 110.4, 60.3, 50.1, 40.3, 34.8, 30.3, 27.1, 16.6, 15.1, 14.2, 11.1.

HRMS $\left(\right.$ ESI $\left.^{+}\right): m / z[M+H]^{+}$calcd for $\mathrm{C}_{18} \mathrm{H}_{26} \mathrm{NO}_{3}$ : 304.1907; found: 304.1911.

CSP-HPLC (233 nm, Chiralcel OD-H, $n$-heptane/iPrOH $=99.8: 0.2$, $40{ }^{\circ} \mathrm{C}, 0.5 \mathrm{~mL} / \mathrm{min}$ ): $t_{\mathrm{R}}=21.15 \mathrm{~min}$ (major), $t_{\mathrm{R}}=27.13 \mathrm{~min}$ (minor).

\section{Ethyl (3S,4R,5S)-4-(Benzothiazol-2-yl)-3-methyl-5-phenylhepta- noate (40)}

Compound 40 was synthesized following general procedure $A$ with $1 \mathrm{c}$ (0.1 mmol), $\mathrm{BF}_{3} \cdot \mathrm{OEt}_{2}$ (0.12 mmol, 1.2 equiv), $\mathrm{EtMgBr}$ ( $3 \mathrm{M}$ in $\mathrm{Et}_{2} \mathrm{O}, 0.15$ mmol, 1.5 equiv), $\mathrm{CuBr} \cdot \mathrm{SMe}_{2}(0.005 \mathrm{mmol}, 5 \mathrm{~mol} \%)$, ligand $\left(R_{c}, S_{p}\right)-\mathbf{L 1}$ (0.006 mmol, $6 \mathrm{~mol} \%)$, and 3d $(0.4 \mathrm{mmol}, 4$ equiv) in DCM $(1 \mathrm{~mL})$. Product 40 was obtained as a pale yellow oil after flash column chromatography $\left(\mathrm{SiO}_{2}\right.$, pentane/EtOAc, 97:3, v/v).

Yield: $22.1 \mathrm{mg}$ (58\%); 94\% ee.

${ }^{1} \mathrm{H}$ NMR $\left(400 \mathrm{MHz}, \mathrm{CDCl}_{3}\right): \delta=8.06(\mathrm{~d}, J=8.1 \mathrm{~Hz}, 1 \mathrm{H}), 7.89(\mathrm{~d}, J=7.9$ $\mathrm{Hz}, 1 \mathrm{H}), 7.49(\mathrm{t}, J=7.3 \mathrm{~Hz}, 1 \mathrm{H}), 7.44-7.33(\mathrm{~m}, 3 \mathrm{H}), 7.29(\mathrm{~d}, J=6.9 \mathrm{~Hz}$, $3 \mathrm{H}), 4.20-4.00(\mathrm{~m}, 2 \mathrm{H}), 3.71(\mathrm{dd}, J=11.5,3.5 \mathrm{~Hz}, 1 \mathrm{H}), 3.12(\mathrm{td}, J=$ 10.8 , 3.7 Hz, $1 \mathrm{H}), 2.27-2.11(\mathrm{~m}, 2 \mathrm{H}), 1.97-1.87(\mathrm{~m}, 1 \mathrm{H}), 1.56-1.39$ $(\mathrm{m}, 2 \mathrm{H}), 1.31-1.17(\mathrm{~m}, 3 \mathrm{H}), 1.01(\mathrm{~d}, J=6.6 \mathrm{~Hz}, 3 \mathrm{H}), 0.58(\mathrm{t}, J=7.3 \mathrm{~Hz}$, $3 \mathrm{H})$.

${ }^{13} \mathrm{C}$ NMR (101 MHz, $\left.\mathrm{CDCl}_{3}\right): \delta=171.6,170.6,152.4,141.3,133.8$, $127.7,127.5,125.8,125.0,123.9,122.0,120.5,59.3,52.3,49.6,39.3$, 30.1, 27.7, 13.6, 13.4, 11.1.

HRMS (ESI $\left.{ }^{+}\right): m / z[\mathrm{M}+\mathrm{H}]^{+}$calcd for $\mathrm{C}_{23} \mathrm{H}_{28} \mathrm{NO}_{2} \mathrm{~S}$ : 382.18353; found: 382.18413.

CSP-HPLC (254 nm, Chiralpak AD-H, $n$-heptane/iPrOH $=99: 1,40{ }^{\circ} \mathrm{C}$, $0.5 \mathrm{~mL} / \mathrm{min}$ ): $t_{\mathrm{R}}=14.79 \min$ (minor), $t_{\mathrm{R}}=16.84 \mathrm{~min}$ (major).
(E)-1- $\{(Z)-2-[(S)$-2-Phenylbutylidene]benzoxazol-3(2H)-yl $\}$ but-2en-1-one $(6)$ and $(E)-1-\{(E)-2-[(S)-2-P h e n y l b u t y l i d e n e] b e n z o x a z-$ ol-3(2H)-yl\}pent-2-en-1-one (7)

In a heat-dried Schlenk tube equipped with a septum and a magnetic stir bar, $\mathrm{CuBr} \cdot \mathrm{SMe}_{2}$ (5 mol\%; 0.05 equiv) and the ligand $\left(R_{c}, S_{p}\right)-\mathbf{L 1}(6$ mol\%, 0.06 equiv) were dissolved in DCM $(1 \mathrm{~mL} / 0.1 \mathrm{mmol}$ of substrate) and stirred under a nitrogen atmosphere for $15 \mathrm{~min}$. Substrate $\mathbf{1 b}$ ( $0.1 \mathrm{mmol}, 1.0$ equiv) was added in one portion. After stirring for 5 min at room temperature, the mixture was cooled to $-78^{\circ} \mathrm{C}$ and $\mathrm{BCl}_{3}$ or $\mathrm{BBr}_{3}(0.12 \mathrm{mmol}, 1.2$ equiv) was added. After $5 \mathrm{~min}$, compound $\mathbf{3 d}$ ( $0.4 \mathrm{mmol}$, 4.0 equiv) was added followed by $\operatorname{EtMgBr}(0.15 \mathrm{mmol}, 3 \mathrm{M}$ in $\mathrm{Et}_{2} \mathrm{O}, 1.5$ equiv). After stirring at $-78^{\circ} \mathrm{C}$ for $3 \mathrm{~h}$, the reaction was quenched with $\mathrm{MeOH}(1 \mathrm{~mL})$ followed by saturated aqueous $\mathrm{NH}_{4} \mathrm{Cl}$ solution $(1 \mathrm{~mL})$ and warmed to R.T. The reaction mixture was extracted with DCM $(3 \times 10 \mathrm{~mL})$. The combined organic phases were dried over $\mathrm{MgSO}_{4}$, filtered and the solvents removed on a rotary evaporator. The oily crude residue was purified by flash column chromatography using a mixture of pentane and EtOAc as eluent. Compounds $\mathbf{6}$ and $\mathbf{7}$ were obtained as inseparable mixtures of isomers in 1.85:1 ratios. Yield $=63 \% ; 33 \%$ ee. (Note: the ee was measured for the corresponding 1,4-addition product obtained under the same reaction conditions).

\section{Compound 6}

${ }^{1} \mathrm{H}$ NMR $\left(400 \mathrm{MHz}, \mathrm{CDCl}_{3}\right): \delta=7.81-7.68(\mathrm{~m}, 1 \mathrm{H}), 7.55$ (ddd, $J=8.6$, 6.2, 3.8 Hz, $1 \mathrm{H}$ ), 7.35 (ddt, $J=7.3,4.4,1.6 \mathrm{~Hz}, 1 \mathrm{H}), 7.32-7.23(\mathrm{~m}, 3 \mathrm{H})$, 7.23-7.17 (m, $2 \mathrm{H}), 7.12(\mathrm{dq}, J=8.4,7.0 \mathrm{~Hz}, 1 \mathrm{H}), 6.82(\mathrm{dq}, J=15.6,6.9$ $\mathrm{Hz}, 1 \mathrm{H}), 6.06(\mathrm{dq}, J=15.6,1.6 \mathrm{~Hz}, 1 \mathrm{H}), 4.70(\mathrm{~d}, J=11.1 \mathrm{~Hz}, 1 \mathrm{H}), 3.69$ (qd, $J=10.8,3.6 \mathrm{~Hz}, 1 \mathrm{H}$ ), 1.73 (ddd, $J=6.9,1.7,0.8 \mathrm{~Hz}, 3 \mathrm{H}$ ), 1.68-1.56 $(\mathrm{m}, 2 \mathrm{H}), 0.67(\mathrm{t}, J=7.3 \mathrm{~Hz}, 3 \mathrm{H})$.

${ }^{13} \mathrm{C}$ NMR $\left(101 \mathrm{MHz}, \mathrm{CDCl}_{3}\right): \delta=193.1,162.8,151.2,145.3,141.2$, 140.7, 130.4, 128.6, 128.5, 127.0, 125.3, 124.6, 120.2, 111.0, 57.1, 48.0, 27.1, 18.5, 11.7.

HRMS $\left(\mathrm{ESI}^{+}\right): m / z[\mathrm{M}+\mathrm{H}]^{+}$calcd for $\mathrm{C}_{21} \mathrm{H}_{22} \mathrm{NO}_{2}: 320.16510$; found: 320.16451 .

\section{Compound 7}

${ }^{1} \mathrm{H}$ NMR $\left(400 \mathrm{MHz}, \mathrm{CDCl}_{3}\right.$ ): $\delta=7.55$ (ddd, $J=8.6,6.2,3.8 \mathrm{~Hz}, 1 \mathrm{H}$ ), 7.41-7.32 (m, $2 \mathrm{H}), 7.32-7.23$ (m, $2 \mathrm{H}), 7.23-7.16$ (m, $2 \mathrm{H}), 7.16-7.08$ (m, $1 \mathrm{H}), 7.06-6.99(\mathrm{~m}, 1 \mathrm{H}), 6.41(\mathrm{dd}, J=15.6,1.7 \mathrm{~Hz}, 1 \mathrm{H}), 4.63(\mathrm{~d}, J=$ $11.1 \mathrm{~Hz}, 1 \mathrm{H}), 3.69(\mathrm{qd}, J=10.8,3.7 \mathrm{~Hz}, 1 \mathrm{H}), 1.91$ (ddd, $J=6.9,1.7,0.8$ $\mathrm{Hz}, 3 \mathrm{H}), 1.57-1.43$ (m, $2 \mathrm{H}), 0.75$ (t, $J=7.3 \mathrm{~Hz}, 3 \mathrm{H})$.

${ }^{13} \mathrm{C}$ NMR $\left(101 \mathrm{MHz}, \mathrm{CDCl}_{3}\right): \delta=193.7,162.3,150.9,146.1,141.2$, $141.0,130.5,128.4,128.3,126.8,124.9,124.2,119.9,110.6,57.3,48.0$, $27.5,18.7,12.0$.

\section{Funding Information}

Financial support from NWO (Vidi and ECHO to S.R.H.) and the Ministry of Education, Culture and Science (Gravity programme 024.001.035 to S.R.H.) is acknowledged. J.M.P. thanks the European Commission for an Intra-European Marie Curie fellowship (grant 746011-ChirPyr).

\section{Acknowledgment}

We also thank Solvias for a generous gift of Josiphos ligands, T.D. Tiemerma-Wegman for HRMS support and Pieter van der Meulen for NMR support. 


\section{Supporting Information}

Supporting information for this article is available online at https://doi.org/10.1055/s-0037-1611657.

\section{References}

(1) (a) Cauble, D. F.; Gipson, J. D.; Krische, M. J. J. Am. Chem. Soc. 2003, 125, 1110. (b) Agapiou, K.; Cauble, D. F.; Krische, M. J. J. Am. Chem. Soc. 2004, 126, 4528. (c) Bocknack, B. M.; Wang, L. C.; Krische, M. J. Proc. Natl. Acad. Sci. U.S.A. 2004, 101, 5421.

(2) (a) Germain, N.; Schlaefli, D.; Chellat, M.; Rosset, S.; Alexakis, A. Org. Lett. 2014, 16, 2006. (b) Posner, G. H.; Webb, K. S.; Asirvatham, E.; Jew, S. S.; Degl'Innocenti, A. J. Am. Chem. Soc. 1988, $110,4754$.

(3) (a) Calvo, B. C.; Madduri, A. V. R.; Harutyunyan, S. R.; Minnaard, A. J. Adv. Synth. Catal. 2014, 356, 2061. (b) den Hartog, T.; Rudolph, A.; Maciá, B.; Minnaard, A. J.; Feringa, B. J. J. Am. Chem. Soc. 2010, 132, 14349. (c) Bleschke, C.; Tissot, M.; Müller, D.; Alexakis, A. Org. Lett. 2013, 15, 2152. (d) Germain, N.; Guenée, L.; Mauduit, M.; Alexakis, A. Org. Lett. 2014, 16, 118. (e) Howell, G. P.; Fletcher, S. P.; Geurts, K.; ter Horst, B.; Feringa, B. L. J. Am. Chem. Soc. 2006, 128, 14977. (f) Brown, M. K.; Degrado, S. J.; Hoveyda, A. H. Angew. Chem. Int. Ed. 2005, 44, 5306. (g) Pineschi, M.; Del Moro, F.; Gini, F.; Minnaard, A. J.; Feringa, B. L. Chem. Commun. 2004, 1244.

(4) (a) Taylor, R. J. K. Synthesis 1985, 364. (b) Guo, H.-C.; Ma, J.-A. Angew. Chem. Int. Ed. 2006, 45, 354. (c) Galeštoková, Z.; Šebesta, R. Eur. J. Org. Chem. 2012, 6688. (d) Germain, N.; Alexakis, A. Chem. Eur. J. 2015, 21, 8597. (e) Feringa, B. L.; Pineschi, M.; Arnold, L. A.; Imbos, R.; De Vries, A. H. M. Angew. Chem. Int. Ed. 1997, 36, 2620. (f) Alexakis, A.; Trevitt, G. P.; Bernardinelli, G. J. Am. Chem. Soc. 2001, 123, 4358.

(5) Degrado, S. J.; Mizutani, H.; Hoveyda, A. H. J. Am. Chem. Soc. 2001, 123, 755.
(6) Jumde, R. P.; Lanza, F.; Veenstra, M. J.; Harutyunyan, S. R. Science 2016, 352, 433.

(7) (a) Reetz, M. T.; Gosberg, A.; Moulin, D. Tetrahedron Lett. 2002, 43, 1189. (b) Schuppan, J.; Minaard, A. J.; Feringa, B. L. Chem. Commun. 2004, 792. (c) Lopez, F.; Harutyunyan, S. R.; Meetsma, A.; Minaard, A. J.; Feringa, B. L. Angew. Chem. Int. Ed. 2005, 44, 2752. (d) Wang, S.-Y.; Loh, T.-P. Chem. Commun. 2010, 46, 8694.

(8) (a) Miura, T.; Nakamuro, Y.; Miyakawa, S.; Murakami, M. Angew. Chem. Int. Ed. 2016, 55, 8732. (b) Selander, N.; Worrell, B. T.; Chuprakov, S.; Velaparthi, S.; Fokin, V. V.J. Am. Chem. Soc. 2012, 134, 14670. (c) Bernardi, A.; Gennari, C.; Goodman, J. M.; Leue, V.; Paterson, I. Tetrahedron 1995, 51, 4853. (d) Florio, S.; Capriati, V.; Luisi, R.; Abbotto, A. Tetrahedron Lett. 1999, 40, 7421. (e) Meyers, A. I.; Yamamoto, Y.J. Am. Chem. Soc. 1981, 103, 4277.

(9) (a) Hatakeyama, T.; Ito, S.; Nakamura, M.; Nakamura, E. J. Am. Chem. Soc. 2005, 127, 14192. (b) Stork, G.; Dowd, S. R. J. Am. Chem. Soc. 1963, 85, 2178. (c) Gates, M.; Zabriskie, J. L. J. Org. Chem. 1974, 39, 222. (d) Wittig, G.; Reiff, H. Angew. Chem., Int. Ed. Engl. 1968, 7, 7. (e) Pearce, G. T.; Gore, W. E.; Silverstein, R. M. J. Org. Chem. 1976, 41, 2797. (f) Kochi, T.; Tang, T. P.; Ellman, J. A. J. Am. Chem. Soc. 2003, 125, 11276. (g) Peltier, H. M.; Ellman, J. A. J. Org. Chem. 2005, 70, 7342. (h) Hayashi, K.; Kogiso, H.; Sano, S.; Nagao, Y. Synlett 1996, 1203.

(10) Madduri, A. V. R.; Harutyunyan, S. R.; Minnaard, A. J. Angew. Chem. Int. Ed. 2012, 51, 3164.

(11) (a) Hamrick, P. J. Jr.; Hauser, C. R. J. Am. Chem Soc. 1959, 81, 493. (b) Stork, G.; Rosen, P.; Goldman, N.; Coombs, R. V.; Tsuji, J. J. Am. Chem. Soc. 1965, 87, 275.

(12) Zhang, Z.; Wang, Z. J. Org. Chem. 2006, 71, 7485.

(13) Roy, I. D.; Burns, A. R.; Pattison, G.; Michel, B.; Parker, A. J.; Lam, H. W. Chem. Commun. 2014, 50, 2865.

(14) Wang, Y. D.; Kimball, G.; Prashada, A. S.; Wanga, Y. Tetrahedron Lett. 2005, 46, 8777.

(15) Evindar, G.; Batey, R. A. J. Org. Chem. 2006, 71, 1802. 